Journal Universitas Muhammadiyah Gresik Engineering, Social Science, and Health International Conference (UMGESHIC)

UMGCINMATIC : $1^{\text {st }}$ Rethinking Education during Covid-19 Era: Challange and Innovation

\title{
GOVERNMENT POLITICS IN BUILDING ISLAMIC EDUCATION POLICY \\ IN MADRASAH ACCORDING TO CHOIRUL MAHFUD IN ISLAMIC EDUCATION POLITICAL BOOK
}

\author{
Tri Rahayu Puji Lestari ${ }^{1}$, Noor Amiruddin ${ }^{2}$, Muyasaroh ${ }^{3}$ \\ ${ }^{1}$ Students of Islamic Education Programs ,Universitas Muhammadiyah Gresik \\ ${ }^{2}$ Lecturer Islamic Education Program, Universitas Muhammadiyah Gresik
}

Email: trirahayupujilestari@gmail.com; amir@umg.ac.id ; muyas@umg.ac.id

\begin{abstract}
ABSTRAK
Madrasas are Islamic Educational Institutions recognized by the Government and their policies are regulated by law. Even so, in reality there are still many problems related to the politicization of teachers and discrimination due to the dichotomy of Madrasah institutions. This research is useful in knowing the political role of the government in developing Islamic education policies and knowing Islamic education policies in Madrasas according to Choirul Mahfud's perspective, so that solutions can be found regarding problems in Madrasas. This research method is a qualitative study of literature (Library Research) from a book by Choirul Mahfud entitled Politics of Islamic Education and at the same time becomes the main reference source. The author also takes from other sources such as journals, theses, books, internet, or other sources. The data analysis technique used descriptive analysis and documentation methods. The results of this study are the Government's role in developing Islamic education policies can be seen from the formation of regulations, such as: BPKNIP Session 28 December 1945, Three Ministerial Decrees, National Education System Law no. 20 of 2003, and PP No. 55 of 2007. The concept of community-based education is an alternative solution to solving various educational problems by establishing the Board of Trustees, BP3, and the Education Foundation. In addition, Minister of Education and Culture Mr. Nadiem Makarim said that, the opening of the selection for the PPPK program is an effort by the government to provide justice to honorary teachers, so that honorary teachers are expected to receive proper welfare.
\end{abstract}

Keyword : Political Role of Government, Islamic Education Policy, Madrasah, Choirul Mahfud 


\section{INTRODUCTION}

The birth of the policy is a form of solving a number of educational problems that occur, especially Islamic education. This, in accordance with Hasbullah's opinion, namely, that policy is the formulation of government decisions that are used as behavioral guidelines in overcoming problems and problems related to the objectives, plans and programs implemented (Armida, 2012).

Madrasah is one of the Islamic educational institutions that has been recognized as part of the national education system so that its position is equivalent to general education institutions. This, as regulated in article 17 and article 18 of Law no. 20 of 2003 concerning the National Education System Even so, in the implementation of Islamic education policies in madrasas, there are still many problems that can interfere with the continuity of the education process in Madrasas(Armida, 2012).

The problem that often arises is the existence of acts of discrimination against Islamic Educational Institutions, as evidenced by the issuance of Circular Letter of the Minister of Home Affairs (Mendagri) Number 903/2429/SJ which prohibits Regional Governments from disbursing APBD funds for donations or assistance to madrasas and religious education institutions, and then received strong protests from local officials including the East Java Provincial Government and local governments throughout Indonesia and even the Ministry of Religion(Armida, 2012). The Ministry of Religion considers that the revocation of the allocation of educational assistance funds that are revoked from madrasa schools and Islamic educational institutions is a form of discrimination against Islamic educational institutions and is considered unfair to Islamic educational institutions, especially madrasas.

The implementation of education in madrasas is often underestimated, because madrasas are considered a "second class" education after formal education held by the Ministry of Education and Culture. Education in madrasas is considered to be of poor quality, because madrasa graduates are considered unable to compete with graduates of equivalent educational units. In addition, the governance of the institution is also not of good quality, which has resulted in some of the community making madrasas as educational institutions of last choice to send their children to school(Armida, 2012).

Islamic education policies that exist in Madrasas need to be responded to and criticized again, because considering that madrasas are Islamic educational institutions recognized by the government, it turns out that there are still many educational problems, especially related to the management of madrasa institutions and PAI teachers which make people less trust in the quality of education in Madrasas, so that Madrasas are often considered as another alternative when parents cannot send their children to public schools. Responding to this, the researcher was moved to 
explain how the government's political role in developing Islamic education policies in Madrasas according to Choirul Mahfud's perspective in order to find solutions related to the problems of managing madrasa institutions and PAI teachers, so that the public can trust the quality of education in Madrasahs and to advance madrasa institutions as Islamic Educational Institutions recognized by the Government. Everything will be explained and summarized in a thesis entitled "The Role of Government Politics in Developing Islamic Education Policies in Madrasas According to Choirul Mahfud in the Book of Islamic Education Politics".

\section{THEORETICAL FRAMEWORK}

a. The Relationship between Politics and Islamic Education

Abdul Haris' opinion in the book "Philosophy of Islamic Education" says that the relationship between politics and Islamic education is positive and negative. Politics from the positive side is due to the mutually beneficial relationship, where the existence of political institutions can provide education for all citizens through all the policies they make without discrimination and politicization (Armida, 2012). Haris (2018) said Therefore, the role of politics greatly determines the direction of education and development. On the other hand, education also influences the politics of power and even the retreat of a nation. Experiences from various countries note that the quality of a nation's education determines the direction of the nation's progress and the human development index (Arikunto\& Suharsimi, 2010)

\section{b. Problems in Madrasas}

The existing education budget for madrasah schools is not proportional to the number of madrasas throughout Indonesia, and the fund is relatively smaller than the education fund for public schools(Arikunto\& Suharsimi, 2010). Apart from budget issues, madrasas are still seen as "one eye" compared to other public schools. This is because there are many obstacles to management in madrasas, including: 1) leadership practices in madrasas are still traditional, namely paternalistic, feudalistic and charismatic leadership; 2) inadequate standards and professionalism of supervisors, principals and teachers; 3) the mindset of madrasa administration that needs to be changed in managing education funds, efficiency based on cost effectiveness should be the working principle of managing education funds(Irawan \&Noval,2019). Another problem is the institutional dichotomy and dualism of the education system. The institutional dichotomy is a policy of separation of authority between national educational institutions under the auspices of the Ministry of Education and Culture and Islamic education institutions under the auspices of the Ministry of Religion (Mahfud, 2016).

c. Choirul Mahfud's Profile in the Political Book of Islamic Education 
Dr. Choirul Mahfud, MIP, M. PdI is a lecturer at the Sepuluh Nopember Institute of Technology Surabaya (ITS). He was born in Ngawi, February 2, 1982. The proof of his love for the development and progress of Islamic education in Indonesia is evidenced by the many studies he has conducted and the many books he has written, including:

1. Multicultural Education" in 2016 was published by Pustaka Pelajar Yogyakarta

2. "Politics of Islamic Education" in 2016 was published by the Yogyakarta Student Library"

3. Character Education" in 2017 was published by Genius Media Malang, etc.

The book "Politics of Islamic Education" is one of his works related to the criticism of his thoughts on all issues in the world of education with how to analyze the complexity of the political policy of Islamic education in Indonesia after the New Order in the frame of policy analysis and so on(Mahfud, 2016).

d. Islamic Education Policy in Madrasas

Muhaimin argues, the beginning of the Islamic education reform policy was after the amendment of the National Education System Law No. 2 of 1989 into the National Education System Law No. 20 of 2003(Mahfud, 2016). Madrasa policies are legally regulated in Law no. 20 of 2003 concerning the National Education System and Government Regulation No. 55 of 2007 concerning Religious Education and Religious Education, PP No. 66 of 2010 concerning the return of the status of BHMN universities to universities organized by the government and the Higher Education Law no. 12 of 2012. The contents of Law no. 20 of 2003 and PP No. 55 of 2007 is to discuss the scope of Islamic education, namely:

a. Religious education is held at all levels and paths of education

b. General education with Islamic characteristics in early childhood education units, basic education, secondary education, and higher education in formal/non-formal channels

c. Islamic religious education includes diniyah education and Islamic boarding schools which are held on formal/non-formal channels(Mahfud, 2016).

\section{RESEARCH METHODS}

The approach in this study uses library research, by collecting information and data with the help of various existing sources such as reference books, similar previous research results, articles, notes, and various journals related to the problem to be solved. This activity is carried out systematically in order to collect, process, and conclude data according to certain methods/techniques to find answers to the problems at hand. Islamic education" (Mahfud, 2016).

The primary data source in this research is the book Politics of Islamic Education by Chirul 
Mahfud. While the secondary data sources are books, articles, e-mails, journals, websites or other sources that are relevant and related to this research. This study uses data collection techniques in the form of documentation, according to Arikunto defining documentation is a technique of finding data to find variables in books, notes, transcripts, newspapers, magazines, photos, minutes,

meetings, agendas, and so on. ${ }^{1}$ This research is literary, so the data analysis method used by the researcher is descriptive analysis by collecting and compiling data, then analyzing the data and presenting it through a narrative description. While the content analysis researchers make conclusions by identifying the content of messages from various books or other related sources. The data that has been collected is then grouped and analyzed its contents critically and then concluded as an answer to the existing problem formulation.

\section{RESULTS AND DISCUSSION}

The government's political role in developing Islamic education policies is the government's role and efforts in overcoming educational problems, especially advancing Islamic education through the policies it establishes. Center) through a session on December 28, 1945. The session discussed the existence of madrasas and Islamic boarding schools as tools and sources of the nation's intelligence, so that they deserve attention, moral and financial support from the government (Shaleh, 1984). Subsequently, the Ministerial Decree (SKB) was issued in 1975 which explained that madrasas were divided into three levels, namely; Madrasah Ibtidaiyah (MI) is equivalent to Elementary School (SD), Madrasah Tsanawiyah (MTS) is equivalent to Junior High School (SMP), and Madrasah Aliyah (MA) is equivalent to Senior High School (SMA) (Shaleh, 1984). The contents of the SKB policy are also explained in more detail in the National Education System Law no. 20 of 2003, namely, Article 30 explains about the implementation of Islamic education in all education channels, namely, formal, nonformal and informal(Shaleh, 1984).

According to Choirul Mahfud's view, highlighting the existing Islamic education policies in Madrasahs regarding 2 things, namely:

1. Management of Madrasah Institutions

Private madrasas in Indonesia are generally established by the community with a high level of religious spirit with the aim of providing general and religious knowledge that will become the provision for the next generation of Muslims (Ismail, 2010). However, what needs to be considered is the balance of elements of financial capital, management, quality of educators, and adequate infrastructure because it is not surprising that we still find many private madrasah in rural areas with poor conditions(Shaleh, 1984). The concept of community-based education is an alternative solution to solving various educational 
problems handled by the government, namely by involving the role of the wider community, because if you look at the education adopted by developed countries is the decentralization of schools and universities, where public awareness of education is very high so it does not they are reluctant to make a substantial moral and material contribution to the survival of educational institutions. According to Shaleh (1984) The process of fostering the relationship between educational institutions and the community that can assist the performance of education managers, including the Board of Trustees, the Educational Supporting Agency (BP3) and the Education Foundation. Shaleh, (1984)The Board of Trustees according to the $\mathrm{KBBI}$ is a board formed to assist the development of a university, organization, and so on(Shaleh, 1984). The task of the board of trustees is to obtain data/information from university managers to solve problems and then distribute it to the community. Educational Supporting Agency is an agency that assists the implementation of education at the school level and is formed from active parents, whose task is to assist in the procurement of school infrastructure so that the teaching and learning process runs more smoothly. According to the $\mathrm{KBBI}$, a foundation is a legal entity that has no members, which is managed by an administrator and established for social purposes such as hospitals and schools(Shaleh, 1984). The foundation is the founder as well as the main person in charge of educational institutions, therefore many foundations are competing to offer more adequate educational facilities(Shaleh, 1984).

2. PAI teacher

Inequality that often occurs to honorary teachers is one of the negative impacts after the issuance of the Five Ministerial Decree concerning the distribution or even distribution of Civil Servants (PNS). According to the KBBI, structuring and equity means structuring, namely the process, method, act of organizing, arranging, compiling(KBBI, 2013) While equity is the process, method, act of equalizing(KBBI, 2013). So, what is meant by structuring and equalizing the contents of the Five Ministerial Decree, namely, the process of rearranging the ratio of academic qualifications, distribution and composition of PNS teachers to suit the needs of each educational unit. The purpose of the arrangement and distribution of PNS teachers is to improve the quality of education through the provision of teachers in the long term, through certification. If the teacher is certified, it is expected that he will become a professional teacher.

The contents of the technical guidelines for the Five Ministerial Decree stated that teachers who have not taught yet must teach in other schools with the obligation to teach at least 24 hours per week, this applies to teachers in both private and public schools. hours per week, it will be a burden and difficulty for the teacher(Siswantari, 2013). FSGI is of the 
opinion that there are 11 bad impacts as a result of the Five Ministerial Decree concerning honorary teachers, where honorary teachers must be willing to be transferred and expelled from state schools, besides that many honorary teachers are fighting for teaching hours without paying attention to teacher capacity building (Mahfud, 2013).

Furthermore, according to Retno Listyarti, the chairman of the Federation of Indonesian Teachers' Unions, the implementation of the Five Ministerial Decree threatens to be fired from state schools, because in achieving the target of 24 hours per week compulsory teaching, public schools prioritize PNS teachers to seek additional teaching hours. Honorary teachers who teach cross-interest subjects such as German, Japanese, computer teachers, and others, are considered safe because not many civil servants teach these subjects. However, honorary teachers who teach general subjects such as; Biology, Physics, Chemistry, PAI, etc. who have served in the school for many years are in danger of being dismissed and the most affected (Sujati, 2014).

In response to this, it is necessary to make efforts to improve the welfare of honorary teachers, including:

1. Decrease the burden of teaching hours for teachers, for example to 20 hours per week. When compared to the burden of teaching hours for lecturers which is only 12-16 hours per week, it is smaller than the burden of teaching hours for teachers.

2. The role of the district/city education office must be more activated so that it can cooperate with schools/education units in regulating teacher teaching hours

3. Teachers with high school certificates may not teach elementary or middle school levels and vice versa. So that elementary school teachers have good qualifications, especially in the field of ICT, they should be given training through the Distance Education Equalization Program(Sujati, 2014). Furthermore, PJJ was explained in Aria Jalil's journal in 1994 with the title "Distance Education", explaining that PJJ is a partner or second choice of conventional education in order to increase access, justice to education services, and improve the quality of human resources so that can keep pace with scientific, socio-economic, cultural, and technological developments (Jalil, 1994).

4. Nadiem Makarim as the current Minister of Education, proposed the opening of the selection of first aid teacher selection as a form of the state in order to provide fair opportunities for honorary teachers to earn a decent income. Furthermore, he explained that the PPPK selection plan was the government's effort to improve services to students through increasing the availability of ASN teachers. 


\section{CONCLUSION}

Based on the discussion and analysis in chapters 1-4, it can be concluded that the government's political role in developing Islamic education policies is through the laws made, namely: BPKNIP Session 28 December 1945, SKB Three Ministers, National Education System Law No. 20 of 2003, and PP No. 50 of 2007. Educational problems can be solved through the concept of community-based education by establishing a Board of Trustees, BP3, and Foundations. The welfare of honorary teachers can be pursued through: reducing the teaching burden of teachers, activating the education office to regulate teacher teaching hours, adjusting teacher certification to education levels, and the PPPK program so that honorary teachers can become ASN.

\section{REFRENCES}

Armida. 2012. "Education Budget System (Study on Education Budgeting System and Effectiveness of the Use of Education Fees and Its Impact on Improving the Quality of Madrasah Aliyah Education in Jambi City)", Journal: Projections, Vol.13 (2), 2012, or visit http:// /www.jurnal.upi.edu/file/armida.pdf.

Arikunto, Suharsimi. 2010. "Research Procedures A Practical Approach", Jakarta: Rineka Cipta Harris, Abd. 2008. "Philosophy of Islamic Education", Sidoarjo: al-Afkar Press Irawan and Achmad Noval. 2019. "Education Financing Management in Private Madrasah Tsanawiyah: A Case Study at MTS Wihdatul Fitri Kab. Bandung”, Journal: Projections, Vol.14 (1) 2019, or visit the page, http://journals.ums.ac.id/ index.php/jmp/article/download/7051/4746. Alexander, Wahyu. 2019. "Education Policy Analysis in Madrasah Perspective”, Journal: Projections, Vol.4 (1) 2019, or visit the page, https://jurnal.stiq-amuntai.ac.id/index.php/al-madrasah/article /view/109.

Jalil, Aria. 1994. “Distance Education”, Projection Journal: 1994, or visit the page, https://www.google.com/url?sa=t\&source=web\&rct=j\&url=http://repository.ut.ac.id/5425 /1/UTBPPJJ-60.pdf\&ved=2ahUKEwi76rarKDxAhVWfSsKHebbDyUQFjABegQIDxAC\&usg=AOvVaw2PkcCx8rOVOAOaiJVbJVfA

KBBI online, Definition of the Board of Trustees, or visit the page Meaning of the Board of Trustees in the Big Indonesian Dictionary (KBBI) | Literature.ID

KBBI online, Definition of Foundation, or visit the page Meaning of the word "foundation" according to the Big Indonesian Dictionary | KBBI.co.id.

KBBI Online, Definition of Structuring, https://www.kamusbesar.com/penataan.

KBBI Online, Definition of Equity, https://www.kata.we.id/equal distribution/.

Kemenaggresik, Data on the Number of Madrasahs in Gresik Regency, https://kemenagresik.com/ Pendidikan-madrasah. 
Mahfud, Choirul. 2016. "Politics of Islamic Education”, Yogyakarta: Student Library

Mizani, Hilmi. 2013. "Madrasah Education (Policy and System of Madrasah Education in Indonesia)", Journal: Projections, Vol.3 (2), 2013, or visit the page, https://www.google.com/url?sa=t\&source=web\&rct =j\&url=http://jurnal.uinantasari.ac.id/index.php/tiftk/article/download/1856/1378\&ved=2ahUKEwjHxbbPlrHuAhWagt gFHdKoD8cQFjAAegQIARAB\&usg=AOvVaw2UEzneoiUW_g9kHyct.

Moleong, Lexy J. 2017. “Qualitative Research Methodology"’, Bandung: Rosdakarya Youth Mustakim, Ode Mohamad Man Arfa Ladamay Mustakim. 2020. "Education Policy”, Sukabumi: Farha Pustaka

Primary, Yoga Anjas. 2019. "Integration of Madrasah Education in the National Education System", Journal: Projections, Vol.10 (1) 2019, or visit the page, http://ejournal.radenintan.ac.id/index.php/tadzkiyyah/article/view/ 3838.

Researchgate.net, (PDF) Book on Politics of Islamic Education in Indonesia (researchgate.net).

Salih, Abdurrahman. 1984. "Madrasah Management, Legislation", Jakarta: tp

Shulhan, Muwahid and Soim. 2013. "Management of Islamic Education”, (Yogyakarta: Teras Publisher)

Siswantari.2013. "Critical Review of the Joint Regulation of the Five Ministers on the Arrangement and Equity of Civil Servant Teachers", Journal: Projections, 2013, or visit the page, https://www.google.com/url?sa=t\&source=web\&rct=j\&url=https: //jurnaldikbud.kemdikbud.go.id/index.php/jpnk/article/download/301/203/\&ved=2ahUKEwic15 nlmqDxAhUR6nMBHZrNAowQFjACegQIDBAC\&usg=AOvVaw2X7oEf5eb4StjTv18oEX90.

The online news site, Revocation of the Minister of Home Affairs SE Budget Fund, https://www.eramuslim.com/berita/nasional/se-mendagri-about-penunjukan-bantuan-keuanganmadrasah-dinilai-diskriminatif.htm\#.X6IYQ_QujIU.

Sujati, H. 2015. "Policy Analysis of Teacher Arrangements and Civil Servants", Journal: Projections, 2015, or visit the page, https://www.google.com/url?sa=t\&source=web\&rct=j\&url=http:/ /prosiding.upgris.ac.id/index.php/pgsd2015/pgsd2015/paper/view/569/524\&ved=2ahUKEwjO0 73ppqDxAhVPXSsKHWs2A0gQFjABegQIBBAC\&usg=AOvVaw3dZ9g_1xjOWnz.JTUhkYQ Uhz.

UU no. 20 of 2003, or visit the page, uuno20th2003ttgsisdiknas.pdf (kemenag.go.id). 